\title{
SHMT1 wt Allele
}

National Cancer Institute

\section{Source}

National Cancer Institute. SHMT1 wt Allele. NCI Thesaurus. Code C104969.

Human SHMT 1 wild-type allele is located in the vicinity of $17 \mathrm{p} 11.2$ and is approximately $36 \mathrm{~kb}$ in length. This allele, which encodes serine hydroxymethyltransferase, cytosolic protein, plays a role in the metabolism of both amino acids and folate. 